Prepared in cooperation with the

PUERTO RICO ELECTRIC POWER AUTHORITY

\title{
Sedimentation Survey of Lago Garzas, Puerto Rico, September 1996
}

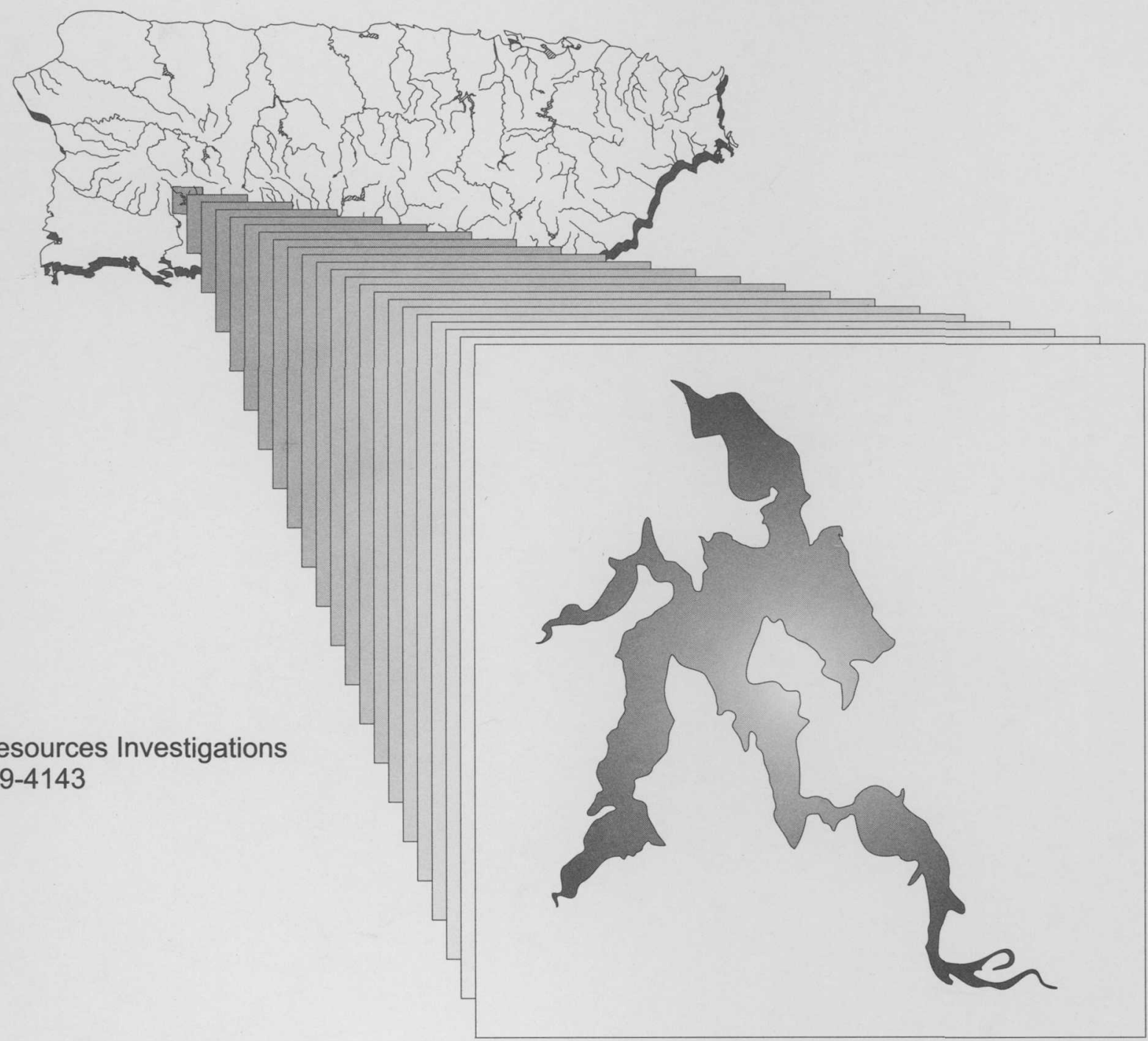




\section{Sedimentation Survey of Lago Garzas, Puerto Rico, September 1996}

By Luis R. Soler-López, Richard M.T. Webb, and Francisco Pérez-Blair

Water-Resources Investigations Report 99-4143

In cooperation with the

PUERTO RICO ELECTRIC POWER AUTHORITY 


\section{U.S. DEPARTMENT OF THE INTERIOR \\ BRUCE BABBITT, Secretary}

\section{U.S. GEOLOGICAL SURVEY}

Charles G. Groat, Director

Use of trade names in this report is for identification purposes only and does not imply endorsement by the U.S. Government.

For additional information write to:

District Chief

U.S. Geological Survey

GSA Center, Suite $400-15$

651 Federal Drive

Guaynabo, Puerto Rico 00965-5703
Copies of this report can be purchased from:

U.S. Geological Survey

Branch of Information Services

Box 25286

Denver, CO 80225-0286 


\section{CONTENTS}

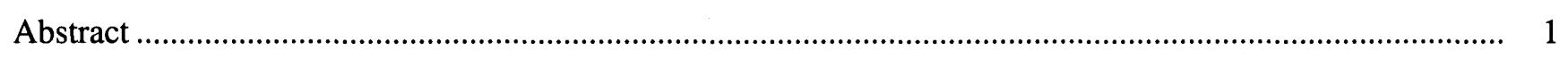

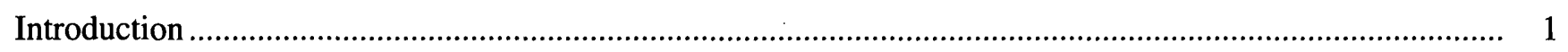

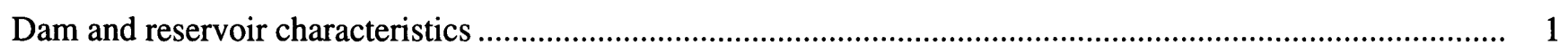

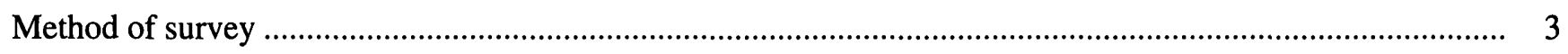

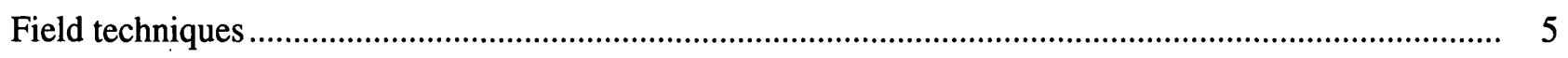

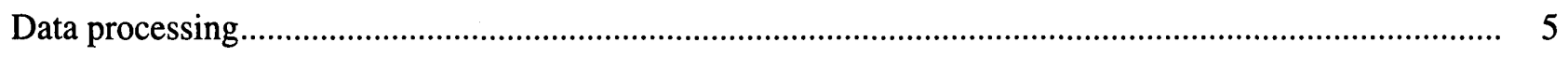

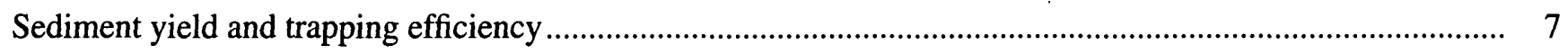

Storage capacity, sedimentation rate and sediment accumulation ...................................................... 18

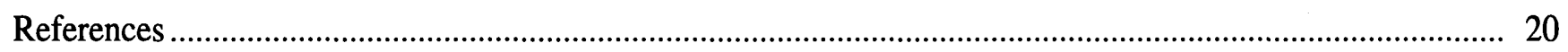

\section{PLATES}

[Plates are in pocket]

1. Lago Garzas, Puerto Rico, Bathymetry, September 1996

2. Lago Garzas, Puerto Rico, Bathymetry, 1978 


\section{FIGURES}

1.-5. Map showing

1. Location of Lago Garzas in the upper Río Grande de Arecibo basin, Puerto Rico

2. Planned cross-section locations for the September 1996 bathymetric survey of Lago Garzas, Puerto Rico

3. Actual track lines of the September 1996 bathymetric survey of Lago Garzas, Puerto Rico ................. 6

4. Reference distances for longitudinal profiles measured in Lago Garzas, Puerto Rico, during the September 1996 bathymetric survey

5. Model cross-section locations for the September 1996 bathymetric survey of Lago Garzas, Puerto Rico

6. Cross sections generated from the TIN surface model of Lago Garzas, Puerto Rico, for 1978 and 1996

7. Comparison of longitudinal profiles measured in Lago Garzas, Puerto Rico, for 1978 and 1996 along the different branches of the reservoir. 16

8. Sediment core locations of the September 1996 bathymetric survey of Lago Garzas, Puerto Rico 17

9. Capacity curves for Lago Garzas, Puerto Rico, for 1978 and 1996

\section{TABLES}

1. Principal characteristics of Lago Garzas and dam as of 1996

2. Average dry bulk density of the sediment cores collected on Lago Garzas, Puerto Rico, December 1996

3. Comparison of prior and current sedimentation surveys of Lago Garzas, Puerto Rico 
CONVERSION FACTORS, DATUMS, ACRONYMS, and TRANSLATIONS

\begin{tabular}{rcl}
\hline Multiply & By & To obtain \\
\hline centimeter & Length & \\
meter & 0.03281 & foot \\
kilometer & 3.281 & foot \\
& 0.6214 & mile \\
square meter & Area & square foot \\
square kilometer & 10.76 & square mile \\
& 0.3861 & \\
cubic meter & Volume & cubic foot \\
cubic meter & 35.31 & acre-foot \\
million cubic meter & 0.0008107 & acre-foot \\
& 810.7 & \\
cubic meter per second & 35.31 & cubic foot per second \\
& Density & pound per cubic foot \\
\hline
\end{tabular}

\section{Datums}

Horizontal Datum - Puerto Rico Datum, 1940 Adjustment

Sea level: In this report, "sea level" refers to the National Geodetic Vertical Datum of 1929 (NGVD of 1929)—a geodetic datum derived from a general adjustment of the first-order level nets of both the United States and Canada, formerly called "Sea Level Datum of 1929."

\section{Acronyms used in this report:}

BLASS Bathymetric/Land Survey System

DGPS Differential Global Positioning System

GIS Geographic Information System

PREPA Puerto Rico Electric Power Authority

TIN Triangulated Irregular Network

USGS U.S. Geological Survey

Translations

Spanish English

Lago Lake

Río River 



\title{
Sedimentation Survey of Lago Garzas, Puerto Rico, September 1996
}

\author{
By Luis R. Soler-López, Richard M.T. Webb, and Francisco Pérez-Blair
}

\section{Abstract}

During September 1996, the U.S. Geological Survey conducted a bathymetric survey of Lago Garzas to determine the storage capacity, average sedimentation rate, and average sediment accumulation within the reservoir. After surveying 72 cross sections, the storage capacity was calculated to be 5.11 million cubic meters. This amounts to a reduction of 0.69 million cubic meters from the original capacity of 5.80 million cubic meters (determined from the 1943 survey), giving a long-term sedimentation rate of about 13,019 cubic meters per year or a capacity loss of about 0.2 percent per year. Later, during December 3-6, 1996, the reservoir sediments were collected and analyzed to determine the dry bulk density of the reservoir sediments. The average dry bulk density of the sediments was 0.66 gram per cubic centimeter. Based on the 15.2 square kilometer sediment contributing drainage area, the average sediment yield of the watershed was estimated to be 565 megagrams per square kilometer per year.

\section{INTRODUCTION}

The U.S. Geological Survey (USGS) in cooperation with the Puerto Rico Electric Power Authority (PREPA) conducted a bathymetric survey of Lago Garzas during September 1996 to determine the storage capacity, the storage loss due to sedimentation, and location of areas of greatest sediment deposition within the reservoir. These data will be useful in evaluating the feasibility of dredging the area in the vicinity of the power outlet gate tower with the objective of rehabilitating one of the sluice gates which is under a thick layer of sediment. Position and water-depth data were collected by using a differential global positioning system (DGPS) coupled to a depth sounder and stored in digital form. The digitized data were transferred into a geographic information system (GIS) where storage volumes and sediment accumulation rates were calculated.

\section{DAM AND RESERVOIR CHARACTERISTICS}

The construction of the Lago Garzas Dam began in 1937 and was completed in 1943. The project was named "Garzas Hydro Electric Project" and was designed by the Rural Electrification Division of the Puerto Rico Reconstruction Administration of the United States Department of the Interior (Puerto Rico Water Resources Authority, written commun., 1978). The dam was constructed for hydroelectric power generation and municipal water use and is located approximately 4.82 kilometers southeast of the town of Adjuntas (fig. 1). The Lago Garzas Dam consists of an earthfill embankment lined with heavy rocks, with dimensions of 61.57 meters height, a top width of 9.14 meters, a base width of 365.76 meters, and a crest length of 277.37 meters. State road PR-518 crosses the top of the dam. A tunnel spillway is located through the left abutment of the dam with a maximum discharge capacity of 528.18 cubic meters per second when the pool elevation is 738.24 meters above mean 


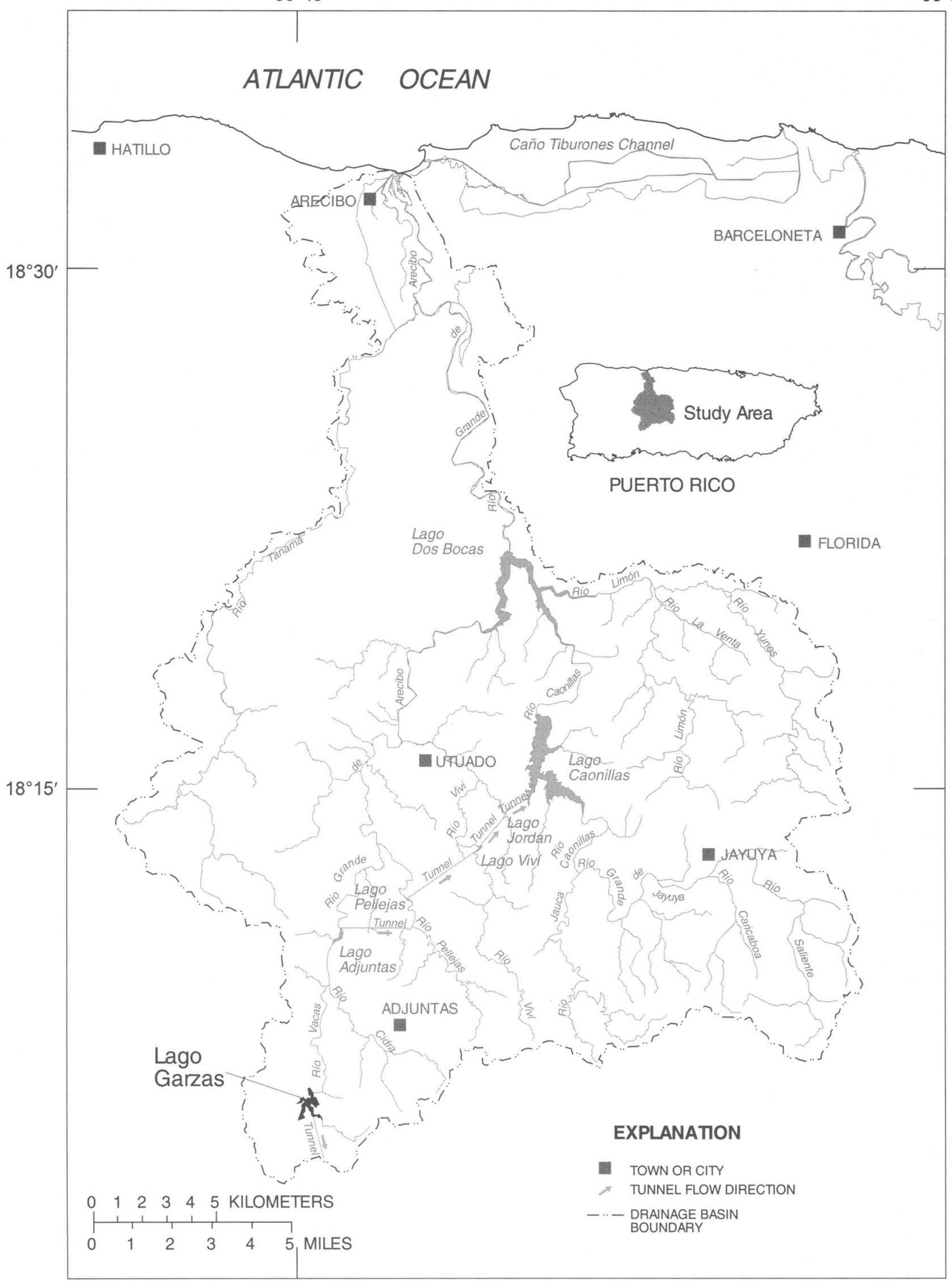

Figure 1. Location of Lago Garzas in the upper Río Grande de Arecibo Basin, Puerto Rico. 
sea level. Water discharges over an uncontrolled morning-glory spillway crest 32.92 meters in diameter, with radial piers. This morning-glory spillway crest has an elevation of 736.12 meters above mean sea level. A sluice outlet is located in the original diversion tunnel through the left abutment of the dam. The sluice outlet has a discharge capacity of 10.76 cubic meters per second with a pool elevation of 736.10 meters above mean sea level. Two power generating outlet gates are located at a tower about 0.8 kilometer upstream from the dam, and about 21.34 meters downstream of the low level inlet of the power generating tunnel. There are two slide gates are located at elevations of 709.82 and 723.91 meters above mean sea level. The drainage area at the damsite of Lago Garzas is 15.6 square kilometers. The principal characteristics of Lago Garzas reservoir and dam are listed in table 1.

\section{METHOD OF SURVEY}

The bathymetric survey of Lago Garzas involved planning, data acquisition, data processing and analysis. A geographic information system, Arc/Info, was used to plan the cross-section locations and for analysis of the collected data. Cross-section locations were established at a spacing of 50 meters starting at the dam up to the different branches of the reservoir (fig. 2). Data were acquired using a DGPS combined with a depth sounder. The pool elevation during the 3 days of the bathymetric survey (September 5-7, 1996) increased from 735.97 to 736.12 meters above mean sea level. The depth soundings were adjusted using a time-elevation correction factor to represent depths below the spillway elevation (736.12 meters above mean sea level). A bathymetric map of the reservoir bottom was then constructed.

Table 1. Principal characteristics of Lago Garzas and dam as of 1996 (Modified from Puerto Rico Water Resources Authority, written commun., 1978)

[All elevations are in meters above mean sea level]

Crest length of dam

Type of spillway structure

Crest diameter

Crest elevation

Depth of vertical shaft

Diameter of vertical shaft

Tunnel length.

Tunnel section

Installed power-generating capacity

Original maximum flood-level storage

Design discharge capacity with maximum flood elevation

(738.24 meters)

Original spillway crest-level storage.

Surcharge storage (flood control)

Drainage area at dam site

1996 flooded area (elevation 736.12 meters)

Maximum height of dam

Maximum original depth of normal pool

Maximum depth during 1996 survey
277.37 meters Morning-glory shape with vertical shaft and horizontal tunnel lined with concrete 32.92 meters 736.12 meters 35.09 meters 6.89 meters 303.28 meters 6.71 meters diameter horseshoe setion none 6.78 million cubic meters 528.18 cubic meters per second 5.80 million cubic meters 0.99 million cubic meters 15.6 square kilometers 0.4 square kilometers 61.57 meters 56.08 meters 30.0 meters 


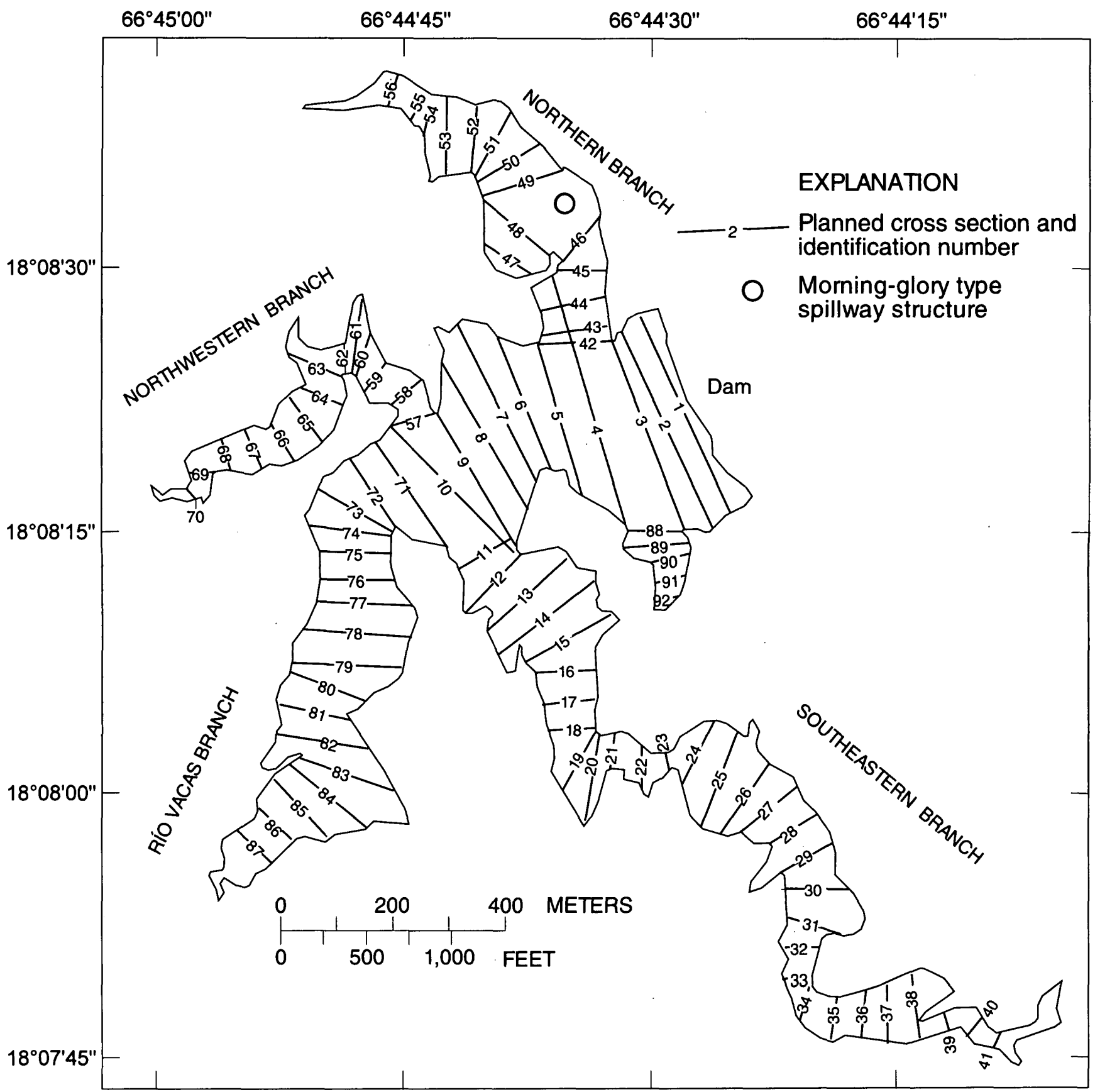

Figure 2. Planned cross-section locations for the September 1996 bathymetric survey of Lago Garzas, Puerto Rico. 


\section{Field Techniques}

Bathymetric field work was conducted during September 5-7, 1996. The bathymetric survey used the Bathymetric/Land Survey System (BLASS), developed by Specialty Devices, Inc. The system uses two Motorola SixGun DGPS receivers for horizontal positioning of the survey boat. The DGPS units were first used in static survey mode to establish a reference mark at a site near the reservoir. Satellite information was recorded simultaneously during a 45-minute session at a previously established survey control station (GUILARTE lat $18^{\circ} 08^{\prime} 30.570^{\prime \prime} \mathrm{N}$., long $66^{\circ} 44^{\prime} 08.383^{\prime \prime} \mathrm{W}$.) and at a reference station overlooking the reservoir (CAFÉ lat $18^{\circ} 08^{\prime} 29.235^{\prime \prime} \mathrm{N}$., long $66^{\circ} 44^{\prime} 30.474^{\prime \prime} \mathrm{W}$.) Post-processing, using the software CentiPoint (GPSsoft, Inc.), showed a horizontal error of less than 10 centimeters for CAFÉ assuming station GUILARTE had no horizontal error.

Once established, CAFÉ was occupied as the master DGPS station and the other DGPS was installed in the survey boat as the mobile station. The DGPS on board the survey boat independently calculated a position every second while receiving a set of pseudo-range corrections from the master station every 5 seconds to maintain positional precision to within 2 meters. Lake depths were measured by using a Raytheon DE-719D depth recorder which gives depths to the nearest 0.1 meter. The depth recorder was calibrated in water depths of 3 and 30 meters. The bathymetric survey software HYPACK (Coastal Oceanographics, Inc.) received and recorded the position and depth once every second while in survey mode. HYPACK runs on a portable personal computer and is used both to record data and to navigate. The helmsman of the survey boat is provided with a graphical display showing the lakeshore, the location of the planned cross sections, the actual position of the boat, and indicators of speed and the amount of deviation from the planned line. A total of 92 cross sections at a 50-meter spacing were planned by using the 1978 unpublished bathymetric survey shoreline. The 1996 shoreline was obtained from aerial photographs taken in 1990 (Caribbean Aerial Survey Inc., written commun., 1991). However, sediment accumulation in some areas limited data collection to only 72 cross sections. Figure 3 shows the actual track lines of the collected data on Lago Garzas. In this report, the numbers identifying planned cross-section lines are different from the numbered cross sections constructed using the computer surface models. These will be referred to as model cross sections.

At the beginning and end of each day of surveying, the survey boat was secured to an assigned location on shore and positional data were recorded for at least 30 seconds, to verify the precision of the DGPS-calculated positions. Random errors can appear in positional data because of GPS calculation errors. Also errors in depth data can occur because of bubbles obstructing the transducer face or because of insufficient fathometer signal gain. Physical or electronic problems encountered in the field were corrected as soon as they were detected. If the section of missing or erroneous data extended more than 20 meters, that cross section was rerun. If the amount of erroneous data occurred for less than 20 meters along the cross section, and the reservoir bottom exhibited no change in slope before and after the section in which data were lost, the section was not rerun but the data file was flagged for later editing.

\section{Data Processing}

Initial editing and verification of the positional and depth data was performed within the HYPACK program. Positions were corrected to eliminate anomalous spikes. Spikes or jumps in the positional data may occur when reception of the satellite's signal is obstructed by local topographic features or disrupted by electromagnetic interference. In such instances, the location of the sounding may be calculated erroneously several hundred meters from the calculated position one second before or one second after. In these cases the erroneous positions were interpolated back to the midpoints between the antecedent and posterior positions. When positional data were lost as a result of elevated land surfaces between the boat and the master station, a signal repeater was installed to "bounce" the signal to the survey boat to avoid loss of data. 


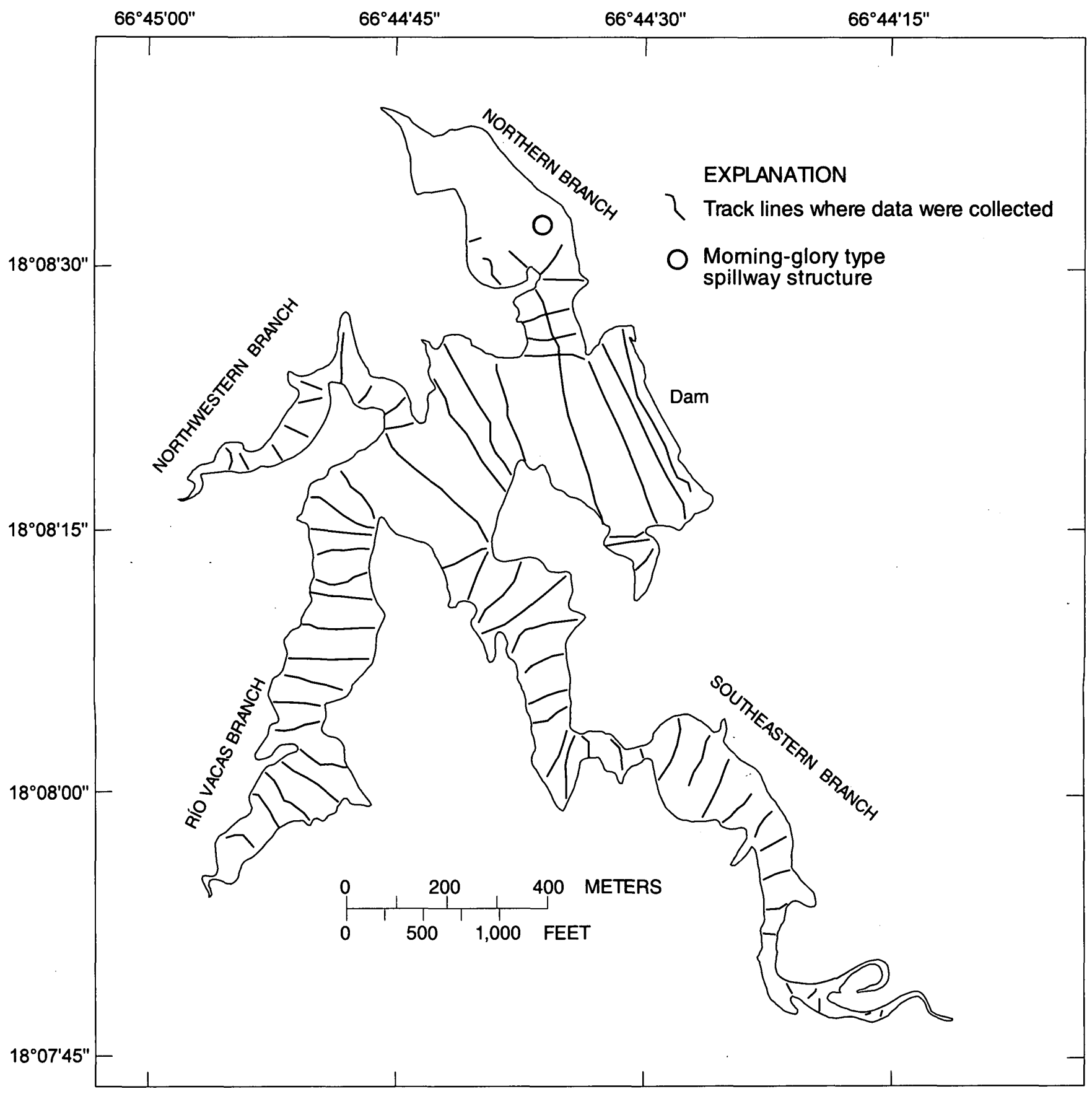

Figure 3. Actual track lines of the September 1996 bathymetric survey of Lago Garzas, Puerto Rico. 
Depth contours were drawn at variable intervals from the deepest part of the reservoir to the shoreline (plate 1). The contours of the unpublished 1978 bathymetry are shown in plate 2 . The contour lines of both surveys were then converted into a surface model by creating a triangulated irregular network (TIN). The TIN models the reservoir bottom as thousands of adjoining triangles with $\mathrm{x}, \mathrm{y}$, and $\mathrm{z}$ coordinates assigned to all vertices. For this study, GIS algorithms were used to calculate volumes of the surface models represented by the 1978 and 1996 contour maps (Environmental Systems Research Institute Inc., 1992). Then the reservoir volume was calculated at incremental pool elevations of 1 meter to generate a stage-storage curve.

Model cross sections and longitudinal profiles across the 1996 TIN were compared with the 1978 bathymetric map to verify that the model sections for both years accurately reflect the reservoir bottom. Longitudinal distances along the Lago Garzas branches where data were collected are shown in figure 4. The model cross-section locations are shown in figure 5. To show the amount of sediment deposited since 1978, the model cross sections are compared in figure 6. Also, the longitudinal profiles along the thalweg of the different branches of the reservoir show the extent and location of the sediment accumulation (fig. 7).

\section{SEDIMENT YIELD AND TRAPPING EFFICIENCY}

The sediment yield of Lago Garzas basin was measured by determining the mass of sediments deposited in the reservoir. During December 3-6, 1996 , sediment cores were collected at seven preselected reservoir sites (fig. 8). A 1- to 2-meter core was recovered from the deepest part of the section using a modified Davis Doyle sediment corer. The samples were then divided into subsamples every 25 centimeters for a dry bulk density determination. These samples were then labeled and sealed in tared plastic containers to be analyzed in the laboratory. After drying each individual sample in the laboratory oven at 105 degrees Celsius for 24 hours, the containers were weighted to determine the dry bulk density of each sample. Results of the laboratory analysis are summarized in table 2 .

Table 2. Average dry bulk density of the sediment cores collected on Lago Garzas, Puerto Rico, December 1996

[The values represent the average of the 25-centimeter subsamples for each site, in grams per cubic centimeter]

\begin{tabular}{lcc}
\hline Site name & Distance from the dam, in meters & $\begin{array}{c}\text { Average dry bulk density, } \\
\text { in grams per cubic centimeter }\end{array}$ \\
\hline GZ-1 & 975 & 0.76 \\
GZ-2 & 900 & 0.61 \\
GZ-3 & 650 & 0.69 \\
GZ-4 & 150 & 0.68 \\
GZ-5 & 475 & 0.64 \\
GZ-6 & 750 & 0.58 \\
GZ-7 & 925 & 0.68 \\
\hline Average & & 0.66 \\
\hline
\end{tabular}




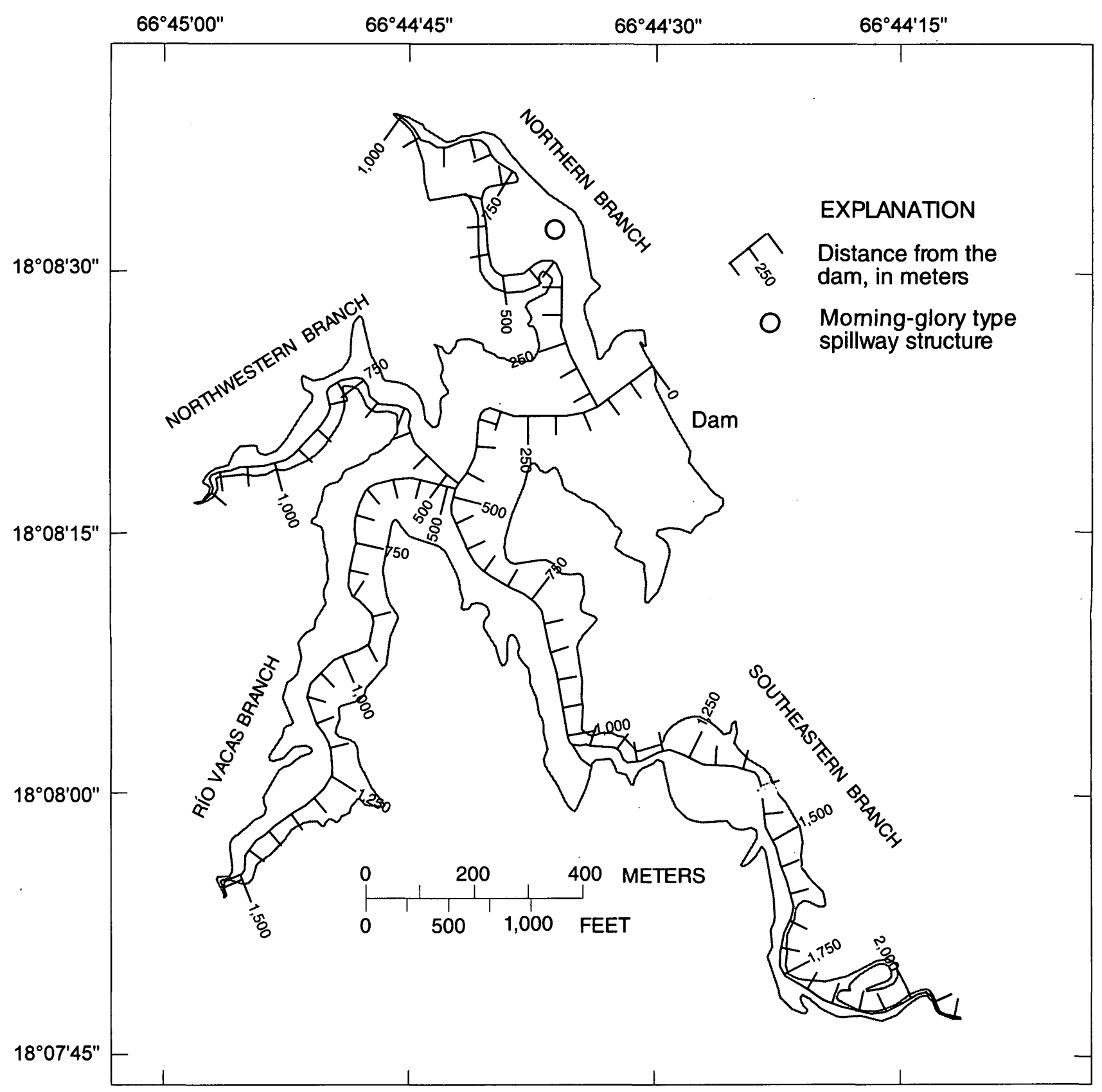

Figure 4. Reference distances for longitudinal profiles measured in Lago Garzas, Puerto Rico, during the September 1996 bathymetric survey. 


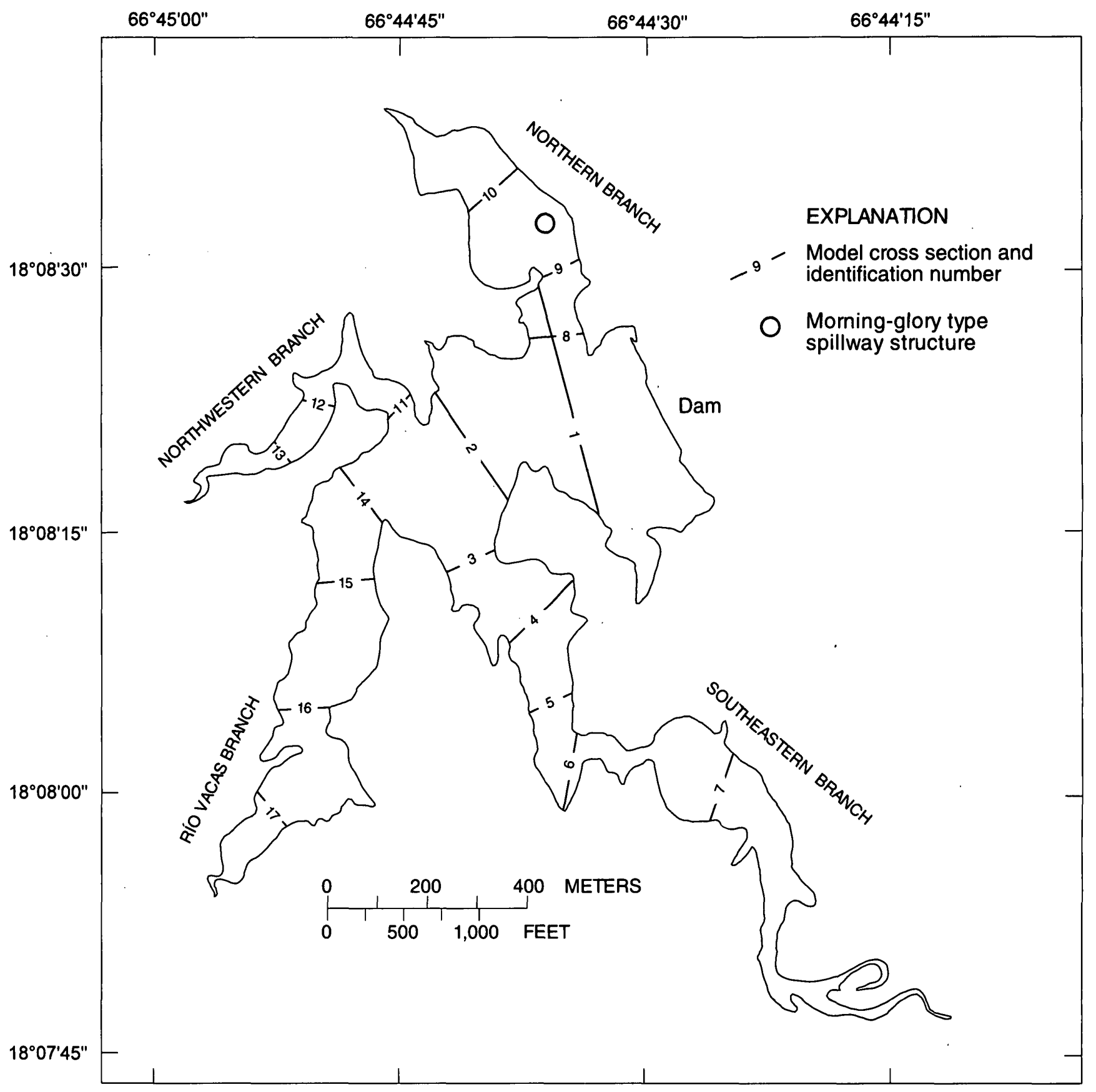

Figure 5. Model cross-section locations for the September 1996 bathymetric survey of Lago Garzas, Puerto Rico. 


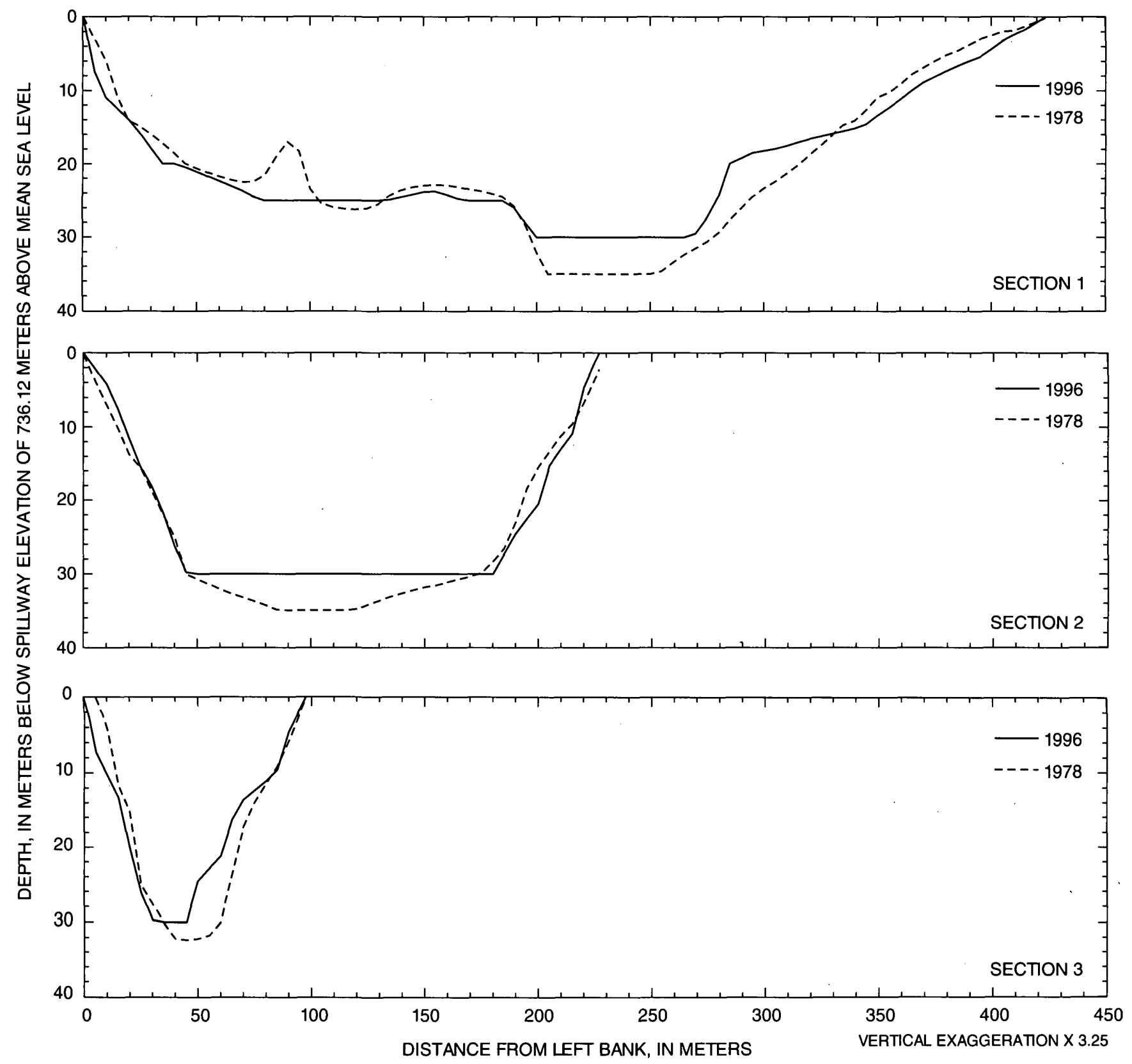

Figure 6. Cross sections generated from TIN surface model of Lago Garzas, Puerto Rico, for 1978 and 1996. [Cross sections are oriented with the observer looking in the downstream direction. Refer to figure 5 for cross-section locations.] 


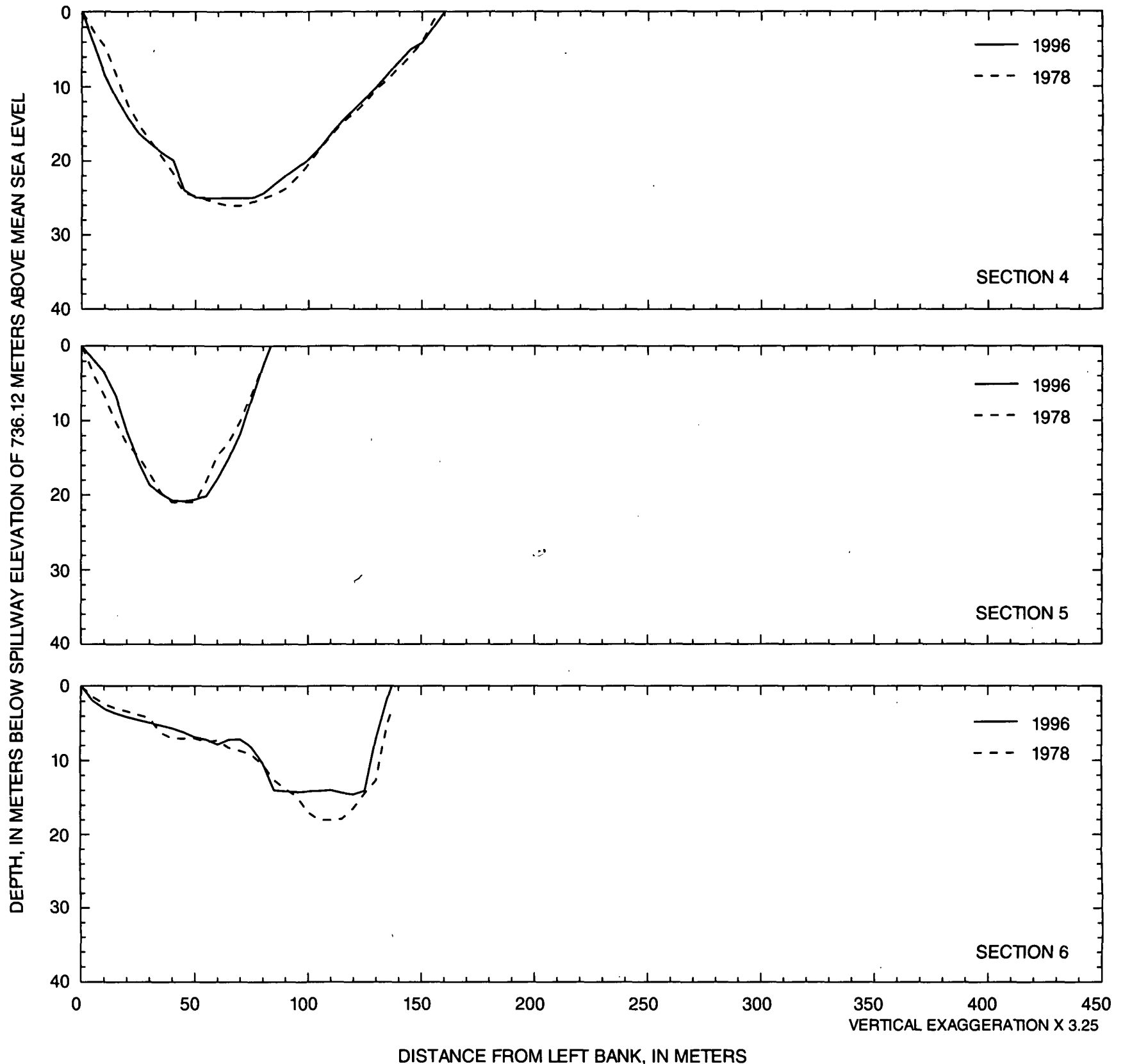

Figure 6. Cross sections generated from TIN surface model of Lago Garzas, Puerto Rico, for 1978 and 1996 — Continued. [Cross sections are oriented with the observer looking in the downstream direction. Refer to figure 5 for cross-section locations.] 


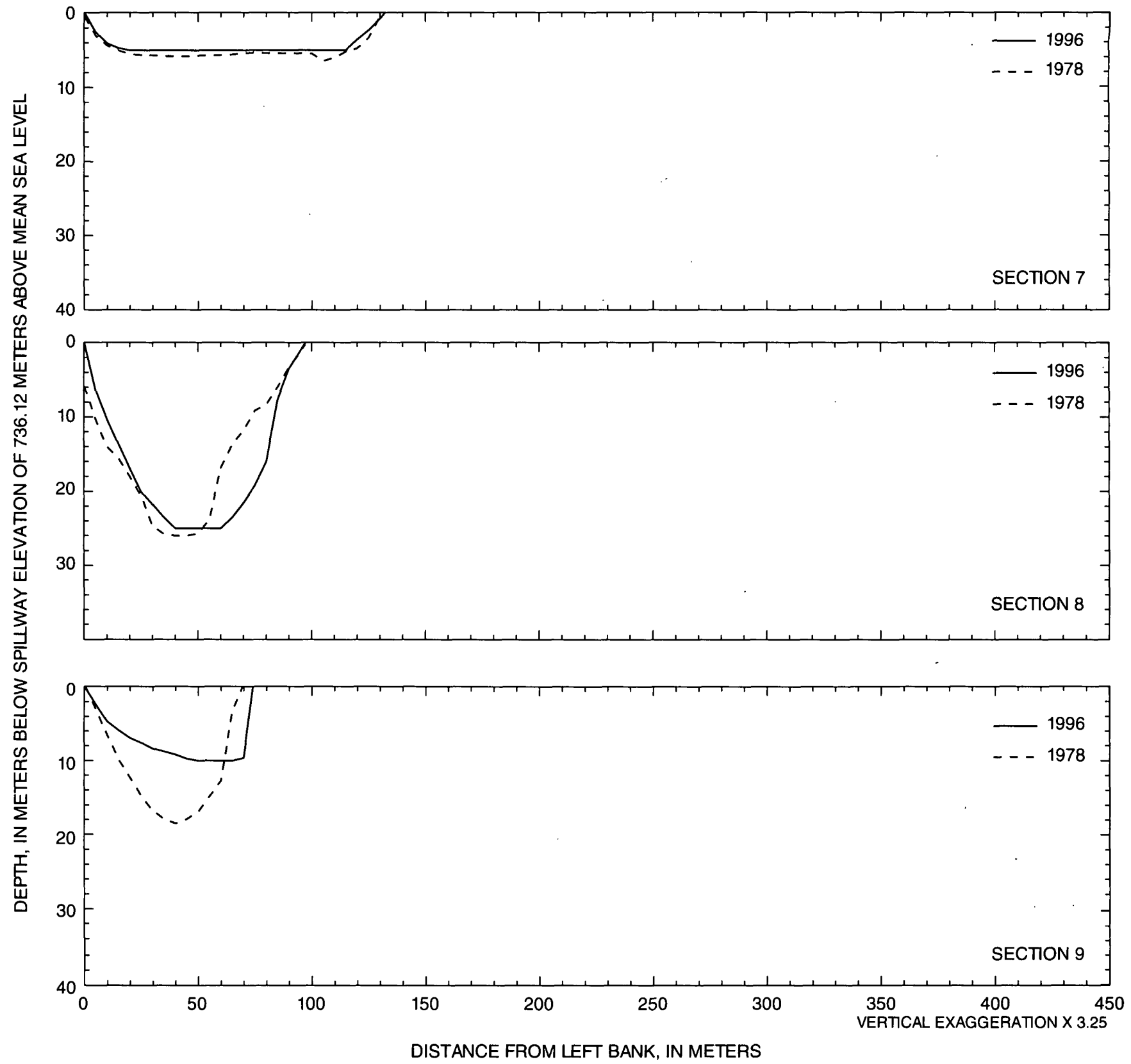

Figure 6. Cross sections generated from TIN surface model of Lago Garzas, Puerto Rico, for 1978 and 1996 - Continued. [Cross sections are oriented with the observer looking in the downstream direction. Refer to figure 5 for cross-section locations.] 


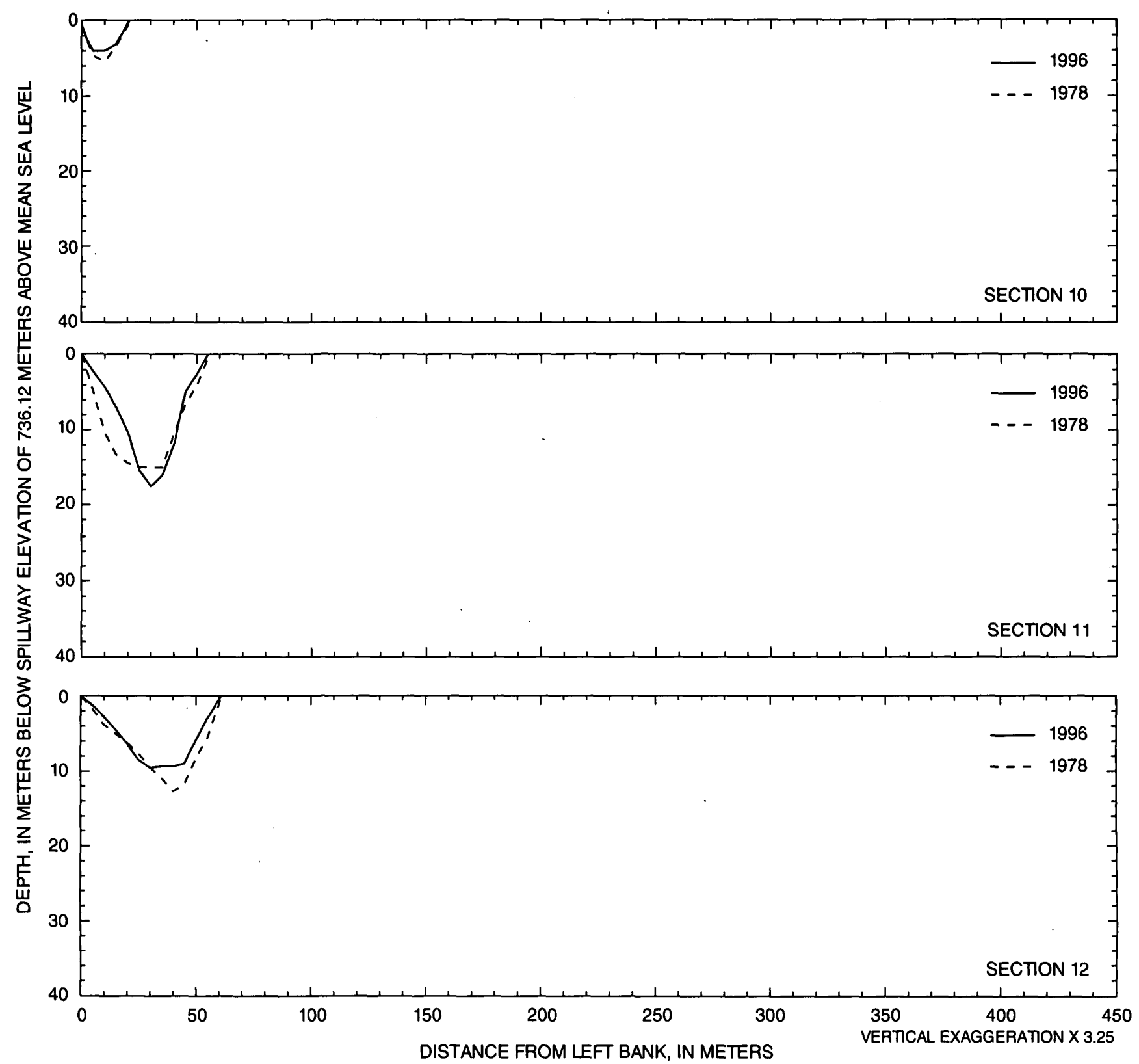

Figure 6. Cross sections generated from TIN surface model of Lago Garzas, Puerto Rico, for 1978 and 1996-Continued. [Cross sections are oriented with the observer looking in the downstream direction. Refer to figure 5 for cross-section locations.] 


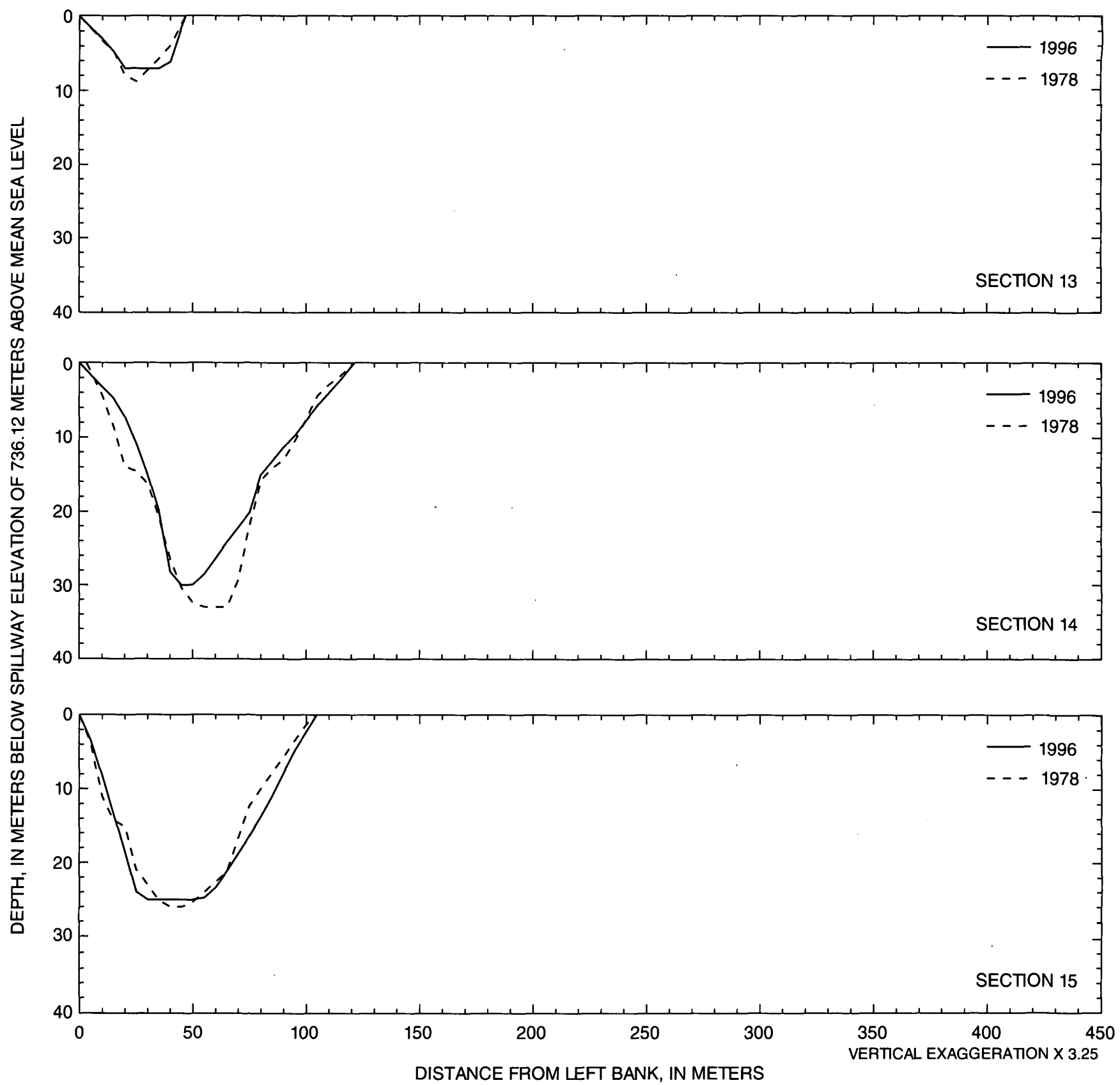

Figure 6. Cross sections generated from TIN surface model of Lago Garzas, Puerto Rico, for 1978 and 1996-Continued. [Cross sections are oriented with the observer looking in the downstream direction. Refer to figure 5 for cross-section locations.] 


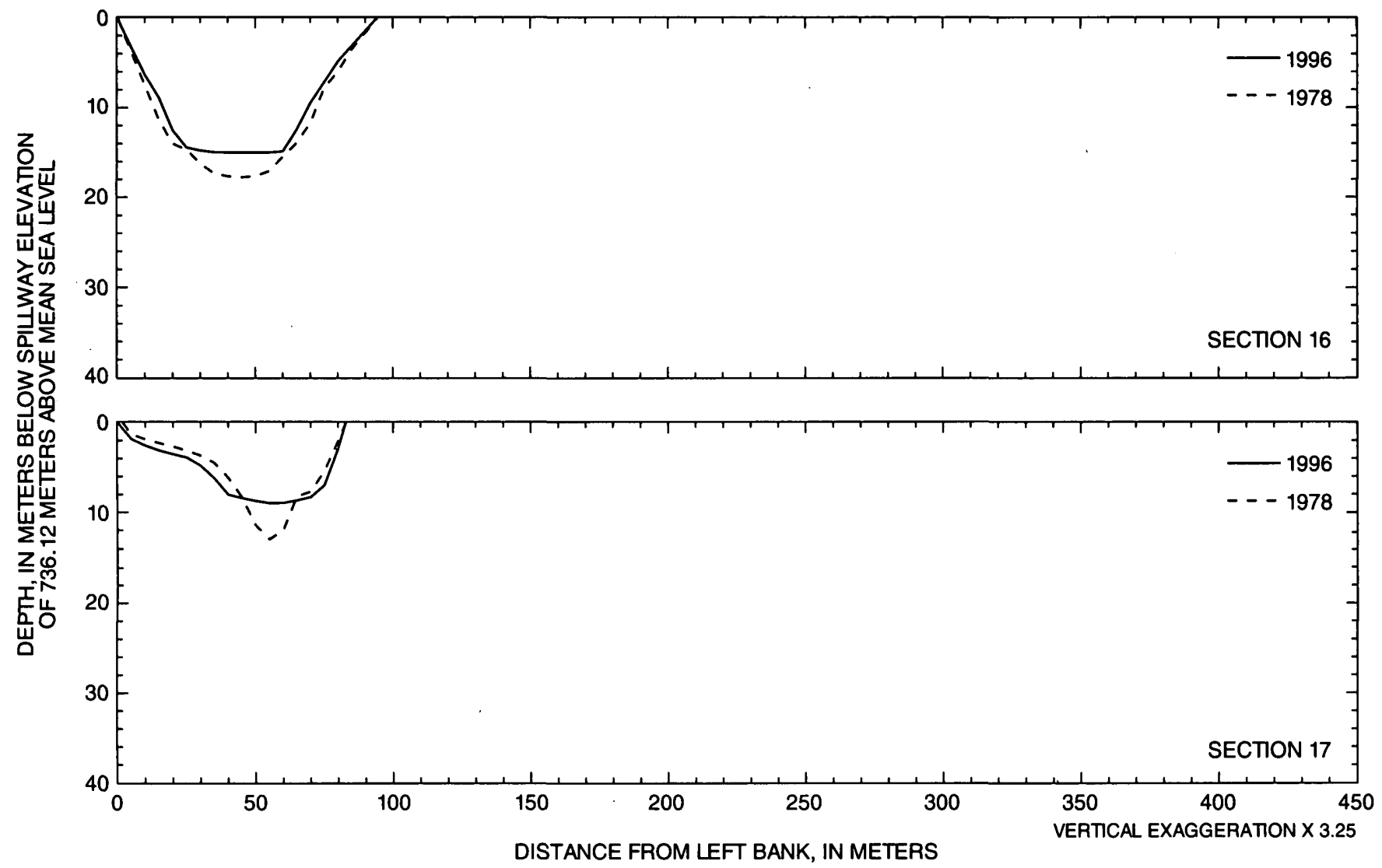

Figure 6. Cross sections generated from TIN surface model of Lago Garzas, Puerto Rico, for 1978 and 1996-Continued. [Cross sections are oriented with the observer looking in the downstream direction. Refer to figure 5 for cross-section locations.] 


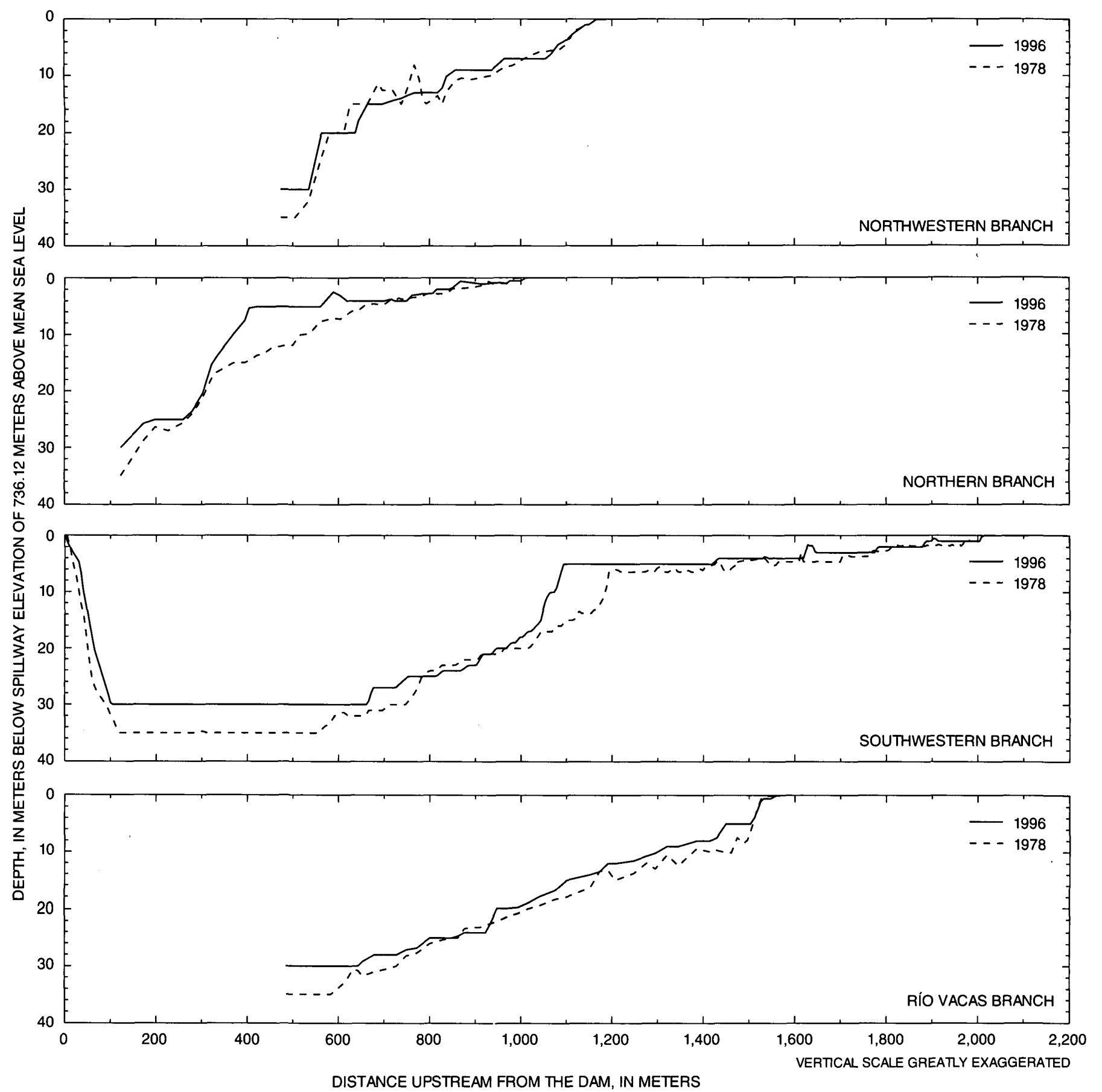

Figure 7. Comparison of longitudinal profiles measured in Lago Garzas, Puerto Rico, for 1978 and 1996 along the different branches of the reservoir. [Refer to figure 4 for the distances and location of the different branches.] 


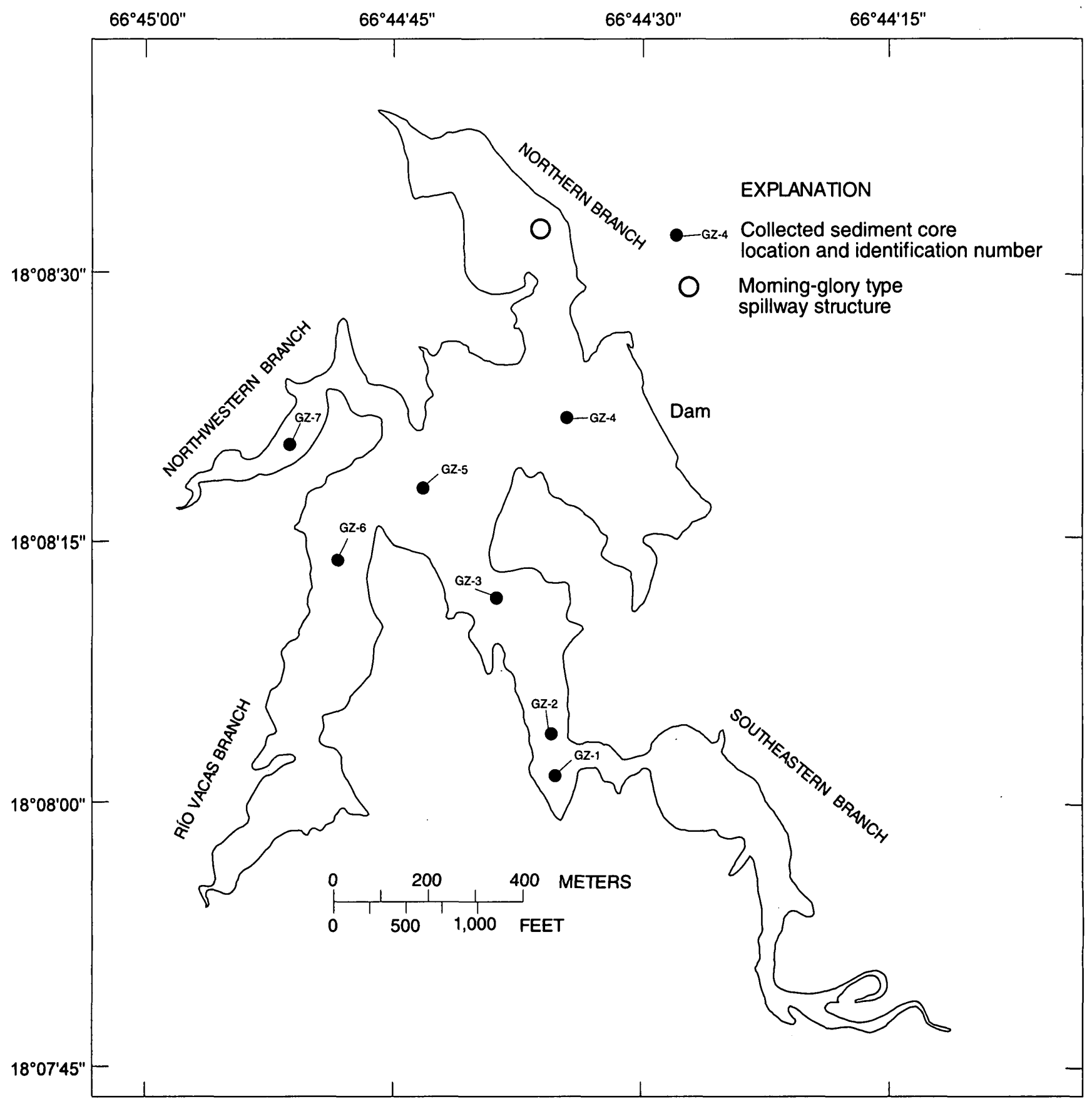

Figure 8. Sediment core locations of the September 1996 bathymetric survey of Lago Garzas, Puerto Rico. 
The computed amount of sediments deposited in the reservoir up to the year 1996 (0.69 million cubic meters) multiplied by the average dry bulk density of the sediments ( 0.66 grams per cubic centimeter) gives the net amount of solid material that has been trapped in the reservoir (455,400 cubic meters). This number divided by the net sediment contributing area (15.2 square kilometers) gives the total amount of solid material deposited per square kilometer $(29,960$ cubic meters). This means that in 53 years, the amount of solid material eroded from the basin that was being trapped in the reservoir was 565 megagrams per square kilometer per year.

The trapping efficiency of the reservoir was estimated by using the capacity/inflow ratio relation described by Brune (1953). None of the Lago Garzas tributaries has a stream gaging station to measure the inflow entering the reservoir. Because of this, the neighboring surface water stream gaging station, Río Saliente at Coabey near Jayuya, Puerto Rico (U.S. Geological Survey station number 50025155), was used to estimate the runoff of the Lago Garzas basin. Average annual rainfall at this gaging station is 2,286 millimeters; the Lago Garzas basin has similar precipitation rates (Calvesbert, 1970). The average annual runoff for the Río Saliente gaging station is 1.09 million cubic meters per square kilometer (Díaz and others, 1996). This normalized runoff rate is assumed to be representative of Lago Garzas basin. The Lago Garzas drainage area is 15.6 square kilometers and the surface area of the reservoir calculated by using the GIS is 0.4 square kilometer. This gives a net sediment contributing area of 15.2 square kilometers. Multiplying the net contributing area by the average annual runoff gives an inflow of 16.6 million cubic meters per year entering Lago Garzas. Using Brune's curve, the trapping efficiency of Lago Garzas is about 95 percent (Brune, 1953).

\section{STORAGE CAPACITY, SEDIMENTATION RATE, AND SEDIMENT ACCUMULATION}

In 1943 the original storage capacity of Lago Garzas was 5.80 million cubic meters, diminishing to 5.58 million cubic meters in 1978 and to 5.11 millions cubic meters in 1996. This is a reduction of 0.69 million cubic meters (12 percent) from the original capacity. Sediment is filling the reservoir at an average rate of 13,019 cubic meters per year, or at an average of 0.2 percent per year. Results of prior and current bathymetric surveys are summarized in table 3 . Capacity curves for the 1978 and 1996 bathymetric surveys are shown in figure 9.

At this sedimentation rate, the continued utility of the reservoir as a water supply for recreational and municipal use is not endangered. However, sediment in the vicinity of the power generating tunnels (about 1,000 meters upstream of the dam, on the southeastern branch of the reservoir) has reached an average elevation of 722 meters above mean sea level. The lowest tunnel intake has an elevation of 709.57 meters above mean sea level. This means that a layer of sediment about 12-meter thick has been deposited since 1943 and is disabling the structure. Sediment accumulation in the reservoir since 1978 has not been uniform (figs. 6 and 7). In the dam area, about 5 meters of sediment has accumulated. In the northern branch, about 9 meters of sediment accumulation is evident in the vicinity of the spillway. This may be the result of flow velocities entering from the small creek being slowed down by the abrupt change in direction of the channel. In the northwestern branch only an average of 2 meters has been deposited. In the Río Vacas branch, sediment accumulation is more uniform. An average accumulation of about 4 meters along the whole branch is observed. This is expected because the major tributary enters the reservoir here. In the southeastern branch, sedimentation is only evident at the intake tower, where about 5 meters has accumulated since 1978. Again, this may be the result of the channel sinuosity, and to some extent, the suction generated by the tunnel intakes. 


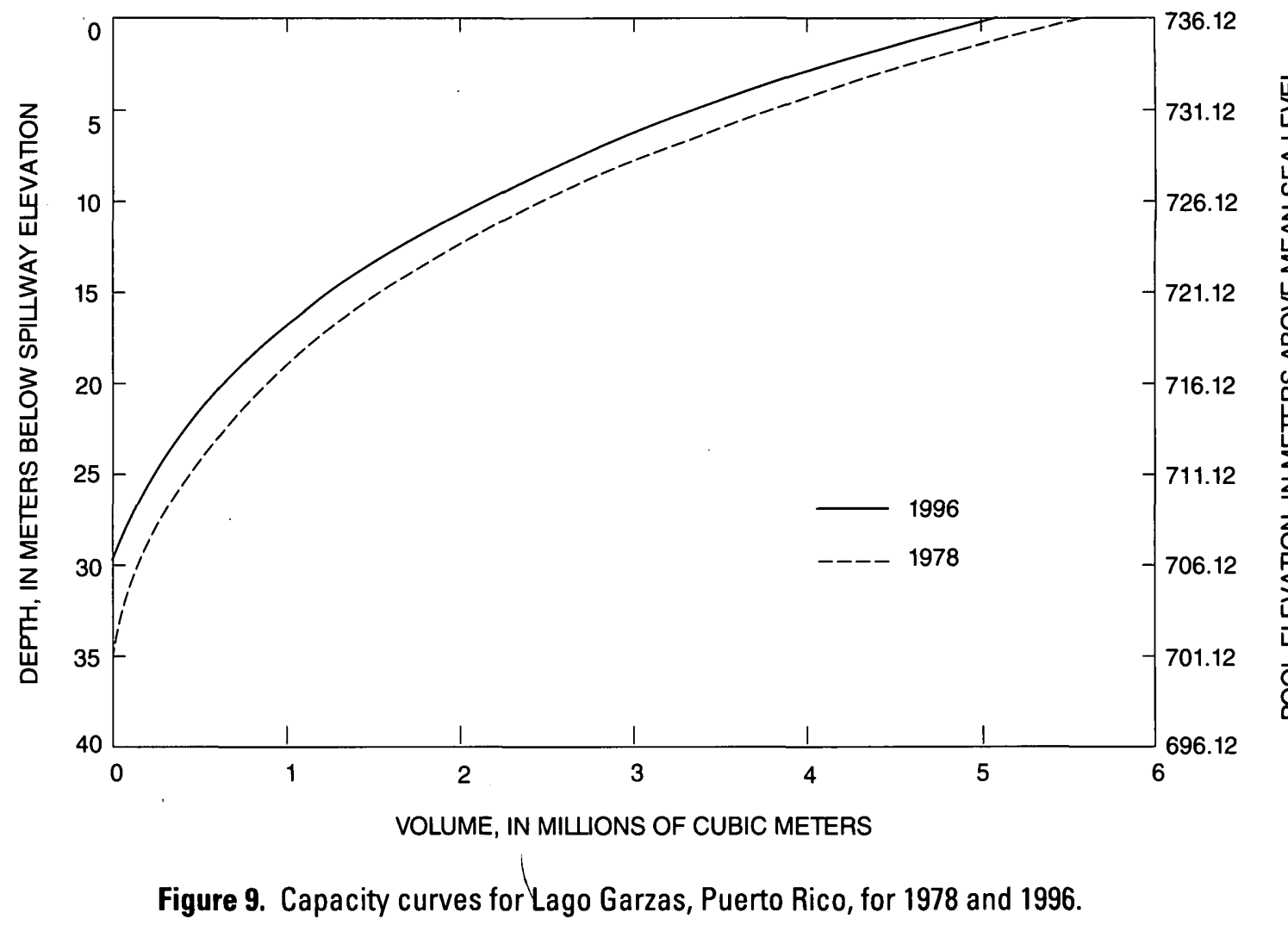

Table 3. Comparison of prior and current sedimentation surveys of Lago Garzas, Puerto Rico

[Elevation datum, National Geodetic Vertical Datum, 1929; TIN, triangulated irregular network; --, not available or undetermined]

\begin{tabular}{|c|c|c|c|}
\hline Year of survey & 1943 & 1978 & 1996 \\
\hline $\begin{array}{l}\text { Capacity in millions of cubic meters (at spillway elevation, } 736.12 \\
\text { meters above mean sea level) }\end{array}$ & 5.80 & 5.58 & 5.11 \\
\hline $\begin{array}{l}\text { Live storage in millions of cubic meters (above top of lower intake } \\
\text { structure, } 709.57 \text { meters above mean sea level) }\end{array}$ & -- & 5.24 & 4.96 \\
\hline $\begin{array}{l}\text { Dead storage in millions of cubic meters (below top of lower intake } \\
\text { structure, } 709.57 \text { meters above mean sea level) }\end{array}$ & -- & 0.34 & 0.15 \\
\hline Years since construction & -- & 35 & 53 \\
\hline Sediment accumulated (millions of cubic meters) & -- & 0.22 & 0.69 \\
\hline Storage loss (percent) & -- & 4 & 12 \\
\hline Long-term sedimentation rate in cubic meters & -- & 6,286 & 13,019 \\
\hline Annual loss of capacity (percent) & -- & 0.11 & 0.2 \\
\hline $\begin{array}{l}\text { Sediment yield in megagrams per square kilometer per year using a } \\
\text { net drainage area of } 15.2 \text { square kilometers }\end{array}$ & -- & $388^{1}$ & $565^{2}$ \\
\hline
\end{tabular}

\footnotetext{
${ }_{1}^{1}$ Assuming a dry bulk density of 1 gram per cubic centimeter and a 100 percent trapping efficiency.
}

2 Using a measured dry bulk density of 0.66 grams per cubic centimeter. 


\section{REFERENCES}

Brune, G.M., 1953, Trap efficiency of reservoirs: Transactions of the American Geophysical Union, v. 34 , no. 3, p. $407-418$.

Calvesbert, R.J., 1970, Climate of Puerto Rico and U.S. Virgin Islands: U.S. Department of Commerce, Environmental Science Services Administration, $29 \mathrm{p}$.
Díaz, P.L., Aquino, Zaida, Figuero-Álamo, Carlos, Vachier, R.J., and Sánchez, A.V., 1997, Water Resources Data-Puerto Rico and the U.S. Virgin Islands, 1996: U. S. Geological Survey WaterData Report PR-96-1, 67 p.

Environmental Systems Research Institute, Inc., 1992, Surface modeling with TIN, Surface analysis and display: Environmental Systems Research Institute, Inc., Redlands, California, p. 4-1, 6-1. 


\section{District Chief}

Caribbean District

U.S. Geological Survey

Water Resources Division

GSA Center, Suite 400-15

651 Federal Drive

Guaynabo, Puerto Rico 00965-5703 